\title{
A Dickens of a funding problem
}

\author{
The financial crisis that continued to grip the world in 2009 has brought the question of who should pay for \\ scientific research - and what it should set out to achieve - into sharper focus than ever.
}

It was the best of times, it was the worst of times, it was the age of wisdom, it was the age of foolishness... So begins the first paragraph of Charles Dickens's A Tale of Two Cities, but scientists could be forgiven for expressing these sentiments with regard to the worldwide funding situation.

UK scientists had funding worries in 2009, beginning with the Engineering and Physical Sciences Research Council turning to a 'three strikes and you're out' policy that would not allow researchers to apply for funding for a full year if they had had three or more proposals rejected over the preceding two years ${ }^{1}$. This was later watered down in the wake of unanimous anger from the research community, who saw the measures as 'draconian' to say the least'.

This was exacerbated by the ongoing debate on how much emphasis should be put on the potential social and economic impact of the proposed research. Some 18,000 people signed a petition demanding that the plan for this to make up 25\% of each assessment should be abandoned by the Higher Education Funding Council for England ${ }^{3}$. The Science Minister, Lord Drayson, faced a fairly hostile audience at a public debate 'Blue skies ahead? The prospects for UK science' at the Wellcome Trust $^{4}$. The level of feeling from the scientific audience can be gathered by Drayson's entry on Twitter": "Just finished \#sciblue debate. Wow. That was heavy. Lots to think about."

Perhaps Drayson should be thankful that the debate was before his Chancellor's prebudget report ${ }^{6}$, which knocked $£ 600$ million off higher education and science and research budgets for 2012-2013. Although the report also included more science-friendly measures, such as an extra $£ 200$ million for innovative industrial projects, universitybased scientists in the UK may be justified in feeling a little concerned for the future ${ }^{7}$.

They may also be looking enviously across the channel at their French counterparts, who on the face of things should be encouraged by their president, Nicolas Sarkozy, announcing a $€ 35$ billion plan to invest in the 'France of tomorrow's,9. Yet there has not been unanimous cheering. On a similar scale to the USA's stimulus package (more below), this is being funded by borrowing from international financial markets and will be targeted at reversing the long neglect of French universities. Following a plan drawn up by a panel led by two former prime ministers, the aim is to create 5-10 elite 'campuses of excellence' that can compete on an international level with, for example, Ivy League universities in the USA or the 'golden triangle' of Oxford, Cambridge and London universities in the UK. "The goal is simple: we want the best universities in the world," Sarkozy said.

Of course, more funding at the top might mean less funding at the bottom, an implication that has not escaped those at smaller or more regional universities. Breaking the long-standing feature of the French system, that all state universities are considered equal in terms of pay structure, could create losers as well as winners unless there are substantial increases in overall funding. It is interesting to note that the UK is using budget cuts in its universities to decrease its national debt while France is increasing its national debt in order to better fund its universities.

Dickens's famous opening line even reflects the situation within a single country: the USA, which has long led the world in both scientific funding and success (pursestring-holders elsewhere paying lip service to scientific quality while slashing budgets may wish to consider whether that is a coincidence). While grant writers across the USA have been busy putting their research hobbies on hold to apply for slices of the stimulus pie, the University of California is facing a financially uncertain time.

The US Congress has voted to give the National Science Foundation a $6.7 \%$ increase to $\$ 6.926$ billion in 2010 - although overall the NSF will actually get less money, not more, in 2010 than in $2009^{10}$. Its regular total was topped up with a healthy $\$ 3$ billion from the economic stimulus package. And Congress has even recommended that President Obama increase the amount that he is rumoured to be asking for NSF for 2011, from $\$ 7.25$ billion to $\$ 7.41$ billion, in order to meet his target of doubling the NSF budget within 10 years.

Heady stuff. So why are some universities in California so cashstrapped that they are planning to charge departments $\$ 100$ per key not returned by graduating students ${ }^{11}$ ? Or more seriously, putting professors and other workers on furloughs amounting to an $8 \%$ pay cut ${ }^{12}$ ?
Because to balance California's state budget, $\$ 30$ billion has been cut in the past two years, $\$ 813$ million this year from the university system alone. Although administrators believe that an end is in sight, what will that end be like, if talented students and faculty are driven away?

Scientists should not be naive enough to believe that they are in a political vacuum that feeds them money and that this comes without strings. A global credit recession will affect everyone, even those within the ivory towers of academia, who are in a position to fare better than many other sectors. And when paymasters are counting pennies, it is not surprising that they will be interested in what return they can see. Researchers should realize that their funding comes from tax paid by an increasingly pinched populace and they should consider whether they can make a meaningful contribution to some of the 'grand challenges' facing the world.

Short-term thinking, however, on the part of governments looking to cut corners and save money does no one any favours, especially in light of studies showing that money invested in research - whether applied or 'blue-skies' - gives a significant pay-back in the long term. Research is the investigation of the unknown so the immediate and future rewards are also hard to forecast ${ }^{13}$. Basic research can yield unexpected avenues that revolutionize everyday life, but applied research can also help to answer fundamental questions. A proper balance of both, with appropriate levels of funding, is surely the only answer.

\footnotetext{
References

1. Nature Mater. 8, 535 (2009).

2. http://www.rsc.org/chemistryworld/News/2009/May/05050904.asp

3. http://www.rsc.org/chemistryworld/News/2009/ December/16120901.asp

4. http://www.newscientist.com/blogs/thesword/2009/12/ukscience-minister-in-the-sto.html

5. http://twitter.com/lorddrayson/status/6212582219

6. HM treasury pre-budget report. Securing the Recovery: Growth and Opportunity p110 (HMSO, 2009); http://www.hm-treasury. gov.uk/d/pbr09_completereport.pdf

7. http://www.sciencecampaign.org.uk/press/releases/2009/ CaSEPBR2009.pdf

8. Enserink, M. Science 326, 1613 (2009).

9. Butler, D. Nature 462, 838 (2009).

10. http://go.nature.com/zjFnCo

11. http://sabbaticalepistles.blogspot.com/2009/12/year-end-giving.html

12. http://www.nytimes.com/2009/11/20/education/20berkeley.html

13. Gibb, B. C. Nature Chem. 1, 513-514 (2009).
} 